\title{
WHY DID BELGIUM PAY LEOPOLD'S BONDS?
}

\author{
KIM OOSTERLINCK, JOSEPH BLOCHER \& MITU GULATI*
}

\section{INTRODUCTION}

King Leopold II's horrific abuse of the Congo Free State (CFS) was a humanitarian disaster of incalculable proportions, ${ }^{1}$ and inspired what has been called the first great international human rights campaign of the twentieth century. ${ }^{2}$ This campaign-which united humanitarian and commercial interests ${ }^{3}$ - eventually forced Leopold to sell the CFS to Belgium, transforming Congo from a private colony to a public one. ${ }^{4}$

Scholars have long noted the ways in which international law-including basic conceptions of sovereignty-shaped and were shaped by the rise and fall of the CFS. How, for example, should law account for the kind of private empire that Leopold ruled? ${ }^{5}$ Both he and Belgium were careful to separate Leopold's roles as monarch of Belgium and as the owner and king of CFS. ${ }^{6}$ Indeed, Leopold

Copyright $(9) 2020$ by Kim Oosterlinck, Joseph Blocher, and Mitu Gulati.

This Article is also available online at http://lcp.law.duke.edu/.

* Kim Oosterlinck is a Professor of Finance at the Université Libre de Bruxelles and Research Fellow at the Centre for Economic Policy Research, and Joseph Blocher and Mitu Gulati are Professors of Law at Duke University. For comments, thanks to Hanoch Dagan, Avihay Dorfman, Anna Gelpern, Roy Kreitner, Jon Macey, Daniel Markovits, Ugo Panizza, Robert Scott, Mark Weidemaier, and participants at the 2019 Market as a Legal Construct conference.

1. See generally AdAM HochSCHILD, King LEOPOLD's GHOST: A STORY OF GREED, TERROR AND HEROISM IN COLONIAL AFRICA (1998), for a discussion of King Leopold's despotism in Africa.

2. E.g., id. at 2; JASON STEARNS, DANCING IN THE GLORY OF MONSTERS: THE COLlAPSE OF THE CONGO AND THE GREAT WAR OF AFRICA 7 (2011).

3. See, e.g., MARTIN EWANS, EUROPEAN ATROCITY, AFRICAN CATASTROPHE: LEOPOLD II, THE CONGO FreE StATE AND ITS AfTERMATH 217-18 (2002) (describing how reports on both the humanitarian crisis and severe trade restrictions helped change Belgian public sentiment regarding the CFS); THOMAs PAKenham, THE SCRAMBle FOR AFricA: THE White MAN's CONQUeST OF THE DARK CONTINENT FROM 1876 TO 1912, at 586 (1990) ("What was new was that these humanitarians had now joined hands with the men of commerce, God with Mammon.").

4. See generally Joseph Blocher \& Mitu Gulati, Transferable Sovereignty: Lessons from the History of the Congo Free State, 69 DUKE L.J. 1219 (2020), for a more complete account of the forced sale, and an argument that the forced sale has important lessons for international law.

5. See generally Steven PRess, Rogue EMPIRES: CONTRACTS AND CONMEN IN EuROPE'S SCRAMBLE FOR AFRICA, 165-218 (2017) (describing Leopold's eventually successful effort to convince the global powers to recognize his corporation's private ownership of the Congo).

6. The relationship between property and sovereignty in the context of the CFS raises many complicated questions, which this Article cannot fully address. It is worth noting, though, that Leopold explicitly demanded that the treaties his representatives signed with native Congolese included articles that "delegate to us their sovereign rights over the territories which are the subject of the said conventions ... .. The treaties must be as brief as possible and in a couple of articles must grant us everything." EWANS, supra note 3 , at 71 (emphasis added). 
pursued the colony in his private capacity precisely because Belgium did not want a colony of its own, ${ }^{7}$ and he governed it like private property, refusing to reveal even the most basic information about his rule. ${ }^{8}$ How complicit was the international law community in effectively recognizing a private sovereignty that merged the roles of sovereign and proprietor? ${ }^{9}$

That legal recognition, in turn, helped to construct-or at least enablecertain kinds of markets. Much has been written about "red rubber," and the ways in which Leopold's voracious pursuit of wealth ruined millions of Congolese lives. ${ }^{10}$ How many lives were lost, and who actually reaped the benefits, remain topics of scholarly and public debate. ${ }^{11}$ But markets also enabled the horrors in the CFS in a more direct but less recognized way: they provided the funds - via the sovereign debt markets - to establish and run the country in the first place. Especially in the early years, Leopold relied heavily on bond markets to finance his sovereign enterprise; when Belgium acquired the colony in 1908, it also acquired - or at least paid - the CFS bonds. ${ }^{12}$ The question that interests us has to do with the willingness of the markets to fund Leopold's genocidal enterprise.

Under the doctrine of odious debts ${ }^{13}$ one might expect the CFS debts to be a prime candidate for repudiation: the debts were clearly undertaken without the consent, and indeed to the detriment, of the Congolese people, and were used to enrich Leopold himself. And yet there seems to have been no realistic

7. See PRESS, supra note 5, at 84 (noting King Leopold's wish to expand Belgium's control, and the domestic opposition he faced).

8. As King Leopold II said before handing over the colony in November 1908, "I will give them my Congo, but they have no right to know what I have done there!" ROGER ANSTEY, KING LEOPOLD'S LEGACY: THE CONGO Under BELgIAN Rule 1908-1960, at 272 (1996). See also HochSCHILD, supra note 1, at 258 (stating that, in King Leopold's words, the CFS was "not beholden to anyone except to its founder .... No one ha[d] the right to ask for its accounts").

9. See, e.g., MARTti KosKenniemi, The Gentle Civilizer of NATIONS: The Rise AND FAll OF INTERNATIONAL LAW 1870-1960, at 155-56 (2002) ("Perhaps the most striking effort to create European sovereignty - and the greatest disappointment about the civilizing mission - can be gleaned in the story of the 'Independent State of the Congo,' created in 1884-85 in part by the private activity of King Léopold II of the Belgians and in part by the concerted action of European powers."); CARL SCHMITT, THE NOMOS OF THE EARTH IN THE INTERNATIONAL LAW OF JUS PUBLICUM EUROPAEUM 214-26 (G.L. Ulmen trans., Telos Press 2003) (1950) (using the CFS to illustrate the disintegration of a spatial legal order).

10. See generally Edmund D. Morel, Red Rubber: THE StORy of THE Rubber Slave Trade FLOURISHING ON THE CONGO IN THE YEAR OF GRACE 1906 (1907) (providing a contemporary report of King Leopold's wealth-driven atrocities in the Congo, and its effect on the millions in the region).

11. See, e.g., HOCHSCHILD, supra note 1, at 225-26 (noting the difficulty of the "historical detective work" necessary to estimate a true figure of lives lost during the CFS).

12. Robert Harms, King Leopold's Bonds, in THE ORIGins of VAluE: The Financial INNOVATIONS THAT CREATED MODERN CAPITAL MARKETS 343, 357 (William N. Goetzman \& K. Geet Rouwenhorst eds., 2005).

13. See JeFF King, The Doctrine OF Odious DebTS In InTERnAtional LAw: A RESTATEMENT 125 (2016) (summarizing governments' ability to repudiate subjugation debts-those whose purpose is actively hostile to the major interests of the population of the debtor state). 
consideration of this possibility, as we discuss in more detail in a separate paper investigating the contemporary scholarly, political, and legal debates. ${ }^{14}$

But what about the markets themselves? An age-old question at the intersection of law, markets, and ethics is whether markets, even in the absence of legal sanctions, constrain certain types of bad behavior. ${ }^{15}$ In the equity context, there is a large body of empirical research asking whether so-called sin securities (for example, stocks in tobacco, gambling, and alcohol companies) suffer a market penalty. Some scholars find that they do. ${ }^{16}$ The reason for the penalty, scholars conjecture, is at least in part that enough investors care about the ethics of their investments to impose a price penalty on the companies in question. ${ }^{17}$ That question is particularly salient in the case of sovereigns, given that there are few formal legal constraints on sovereigns doing bad things to their own people. ${ }^{18}$

Our goal in this Article is to use King Leopold's reign - as sinful as they come, and eventually recognized as such - to measure the market penalty for sin in the sovereign borrowing markets. In particular, we focus on the prices and yields to maturity (YTMs) ${ }^{19}$ on the loans issued by King Leopold on behalf of the CFS between 1885 and 1908. Data on that borrowing implicates two related questions about despotic sovereign borrowing. The first question is whether, once the despotism is revealed to the public, the markets begin to penalize the borrower. The second is whether the successor government to the despot receives a market reward for paying those creditors who funded the despot.

The answers to these questions, in turn, may have much to tell us about lawand, in particular, the doctrine of odious debts. On the one hand, a market penalty for sinful bonds might be taken as evidence of the doctrine's existence: perhaps it signals concern that the debts will be repudiated by a successor. On

14. Joseph Blocher, Kim Oosterlinck \& Mitu Gulati, King Leopold's Bonds and the Mystery of Odious Debts, 60 VA. J. INT'L L. (forthcoming 2020).

15. See, for example, Frederick Schauer, The ForCe of LAW (2015); Robert C. Hughes, Would Many People Obey Non-Coercive Law?, 9 JURIs. 361 (2018), for discussions on whether society may constrain conduct without legal sanctions.

16. E.g., Stefano Collonello, Giuliano Curatola \& Alessandro Gioffre, Pricing Sin Stocks: Ethical Preferences vs. Risk Aversion, 118 EuR. ECON. REV. 69 (2019); William Ming Yang Cheng \& Desmond Lam, Comparing the Price of Sin: Abnormal Returns of Cross-Listed Gaming Stocks in the Hong Kong and US Markets, 45 InT'L J. HosPitAlity MGMT. 73 (2015); Robert B. Durand, SzeeKee Koh \& Paul L. Tan, The Price of Sin in the Pacific Basin 21 PaC. BAsIn Fin. J. 899 (2013); Frank J. Fabozzi, K.C. Ma \& Becky J. Oliphant, Sin Stock Returns, 35 J. Portfolio MGMT. 82 (2008); Julie M. Salaber, The Determinants of Sin Stock Returns: Evidence on the European Markets, (2007 draft), https:// papers.ssrn.com/sol3/papers.cfm?abstract_id=1071746 [https://perma.cc/N783-SSS2].

17. E.g., Harrison G. Hong \& Marcin Kacperczyk, The Price of Sin: The Effect of Social Norms on Markets, 93 J. FIN. ECON. 15 (2009); Harrison G. Hong \& Leonard Kostovetsky, Red and Blue Investing: Value and Finance, 103 J. Fin. ECON. 1 (2012).

18. Ugo Panizza, Federico Sturzenegger \& Jeromin Zettelmeyer, The Economics and Law of Sovereign Debt and Default, 47 J. ECON. LITERATURE 651 (explaining that the primary constraints on opportunistic defaults by sovereign debtors have long been non legal).

19. YTM represents the total return a bond will provide on its purchase price if held to maturity, expressed as an annual rate. This calculation provides a standard measure to gauge the returns of fixedincome securities with differing expiries. See ZVI Bodie, Alex Kane \& Alan J. Marcus, INVESTMENTS AND PORTFOLIO MANAGEMENT 479 (9th ed. 2011). 
the other hand, if successor governments receive market rewards for paying despots' debts, that may help explain why the doctrine is so hard to observe in practice-after all, the legal rights it creates are in the nature of an option, the exercise of which might not have sufficient value. Perhaps Belgium could have legally repudiated the debts, but had political or even moral reasons not to. This exemplifies a tough evidentiary problem for advocates of the odious debt doctrine, since the standard definition of customary international law requires evidence of nations following a rule out of a sense of legal obligation. ${ }^{20}$ If nations have no financial incentive to repudiate, the market will effectively hide any evidence of the legal rule. ${ }^{21}$

To examine whether markets penalized King Leopold II's despotism or rewarded Belgium for honoring the CFS bonds, this Article proceeds in five parts. Part II explains how sovereign debt markets may respond to despotism or incentivize payment of sinful debts using two contemporary examples. Part III describes prior research on the late nineteenth and early twentieth century debts of colonies (of which the CFS bonds are a part) and describes the Article's dataset. Part IV analyzes the data and finds that sovereign debt markets neither penalized the CFS bonds once King Leopold's despotism was uncovered, nor rewarded Belgium for continuing to honor the bonds after purchasing the CFS. Part V concludes.

\section{II}

\section{MARKET RESPONSES TO DESPOTIC SOVEREIGNS}

To explicate the relevance of this inquiry, we begin with two contemporary and familiar examples: Venezuela in 2017 and South Africa in 1994, which neatly map onto the two questions we raised earlier. The first involves the markets' treatment of despotic borrowers; the second involves the incentives of sovereigns to pay sinful debts.

\section{A. Sovereign Sin Penalties: Venezuela 2017}

On May 26, 2017, Harvard economist and former Venezuelan Finance Minister Ricardo Hausmann penned an op-ed titled "Venezuela's Hunger Bonds." 22 The article urged investors to consider the humanitarian crisis in Venezuela; one that was being exacerbated by the Venezuelan government's decision to pay coupons on its foreign debt obligations instead of purchasing

20. See Curtis A. Bradley \& Mitu Gulati, Withdrawing from International Custom, 120 YALE L.J. 202, 209 (2010) ("The standard definition of CIL [customary international law] is that it arises from the practices of nations followed out of a sense of legal obligation. Under this account, there are two elements to CIL: an objective state-practice element and a subjective sense-of-legal-obligation (or opinio juris) element.") (internal citations omitted).

21. We are grateful to the symposium participants for an engaging discussion on this point.

22. Ricardo Hausmann, Venezuela's Hunger Bonds, PROJECT SYNDICATE (May 26, 2017), https://www.project-syndicate.org/commentary/maduro-venezuela-hunger-bonds-by-ricardo-hausmann2017-05 [https://perma.cc/BU7T-T532]. 
vitally necessary medicine and food for its people. The support that foreign bond investors were providing the Maduro government in Venezuela, Hausmann argued, had become a proximate cause of the crisis in that country. Hausmann appealed to the moral sentiments of investors, asking that they move their investments to less harmful settings. ${ }^{23}$

Roughly around the same time, news came out that Goldman Sachs had purchased $\$ 2.8$ billion in bonds of the Venezuelan state-owned oil company, Petroleos de Venezuela (PDVSA), on May 23rd, just a few days prior to the publication of Hausmann's op-ed. ${ }^{24}$ The purchase had been made at thirty-one cents on the dollar for a total price of $\$ 865$ million, an exceptionally deep discount from the face value of the bonds. ${ }^{25}$ This was, in a sense, precisely the type of investment that Hausmann had pleaded with Wall Street not to make. Media reacted with outrage at the news of Goldman Sachs's behavior and started referring to the PDVSA bond as the "Hunger Bond."26

The bond became a pariah. None of the big investors would touch it, which meant that the small investors did not want it either. The bond YTM rose almost 500 basis points within the first five days from when the media storm broke and Goldman Sachs lost almost \$50 million in the market value of its new asset (in addition to not being able to unload it). ${ }^{27}$ Two years later, in late 2019, the Hunger Bond still trades at a significant discount to other similar Venezuelan bonds. ${ }^{28}$

The story of the Hunger Bond raises the question of whether the bond markets have reacted similarly in other situations, penalizing obviously sinful borrowing by sovereigns. That question is so important because there are relatively few formal legal constraints on unethical or sinful sovereign borrowing. Scholars and activists have been arguing for years that a doctrine of odious debts should be recognized by the international community, ${ }^{29}$ but those efforts have generally failed. To the extent social disapproval can work to substitute for the

23. Id.

24. Jana Kasperkevic, What You Need to Know about Venezuela's 'Hunger Bonds', MARKETPLACE (May 31, 2017), https://www.marketplace.org/2017/05/31/what-you-need-know-about-venezuela-shunger-bonds/ [https://perma.cc/F5U2-3TSQ].

25. Id.

26. See, e.g., Kejal Vyas et al., Goldman Sachs Under Fire for Venezuela Bond Deal, WALL ST. J. (May 30, 2017), https://www.wsj.com/articles/goldman-sachs-under-fire-for-venezuela-bond-deal-1496 100583 [https://perma.cc/EVC5-52SQ]; Opinion, Banks Are Right to Shun Venezuela's Hunger Bonds, FIN. TIMES (Aug. 11, 2017), https://www.ft.com/content/0490f1e8-7e83-11e7-ab01-a13271d1ee9c [https://perma.cc/Z5F6-PS8F].

27. See generally Mitu Gulati \& Ugo Panizza, The Hausmann-Gorky Effect, J. BUS. ETHICS (forthcoming 2019), https://link.springer.com/article/10.1007/s10551-019-04132-9 [https://perma.cc/ 9M3L-LRMP], for a detailed discussion of the market response to the Hunger Bond revelations.

28. Mark Weidemaier \& Mitu Gulati, The Puzzling Pricing of Venezuelan Bonds, CREDITSLIPS (Oct. 5, 2019, 3:32 PM), https://www.creditslips.org/creditslips/2019/10/the-puzzling-pricing-ofvenezuelan-sovereign-bonds.html [https://perma.cc/Q4CA-FMPN].

29. See generally Michael Kremer \& Seema Jayachandran, Odious Debts, 96 AM. ECON. REV. 82 (2006); Ricardo Hausmann \& Ugo Panizza, Odiousness Ratings for Public Debt, PROJECT SYNDICATE (Aug. 30, 2017), https://www.project-syndicate.org/commentary/odiousness-ratings-public-debt-byricardo-hausmann-and-ugo-panizza-2017-08?barrier=accesspaylog [https://perma.cc/HB9A-8Z2G]. 
absence of a legal regime, perhaps this can be a useful tool for activists seeking to limit market support for regimes such as the current one in Caracas. Knowing the history of when and why social approval has either worked or not to impose a market penalty on bad sovereigns is important for anyone seeking to utilize this strategy.

With respect to sovereign bonds, some studies have found that markets impose a YTM penalty on bonds that were either issued by despotic governments or whose proceeds were used for ill purposes..$^{30}$ Most directly comparable to the Hunger Bond is the story told by economic historians Collet and Oosterlinck. They find that, in 1906, when the Russian Tsar issued a bond for which he had failed to obtain appropriate legislative approvals, the Tsar's actions were severely criticized in the European press and the market imposed a significant penalty on the bond issuances. ${ }^{31}$ In a different article, Collet investigates the treatment of certain Spanish bonds backed by Cuban resources, whose proceeds had been used to put down the Cuban independence movement. ${ }^{32}$ She finds that, in the wake of the Spanish-American War, the markets imposed a steep discount on these particular bonds as compared to the other Spanish bonds whose proceeds were presumably used for more mundane purposes. ${ }^{33}$ In another article, Oosterlinck finds that the bonds issued by the Nazi-supported government of Vichy France traded at a discount to bonds issued by France's prior legitimate government. ${ }^{34}$

These findings return us to the story at the heart of this Article: that of the CFS. At the start of his venture in the CFS in the 1880s, Leopold claimed that his motives were benevolent and that he wanted to eradicate Arab slavery and bring civilization and free trade to the natives. ${ }^{35}$ Some might even have believed him. But by 1904 at the very latest,${ }^{36}$ Leopold had been revealed to be the overlord of a regime that put profit above any humanitarian concerns (or constraints, for that matter).$^{37}$ Relevant for our purposes is the fact that Leopold issued debt all

30. More tangentially, there are a handful of papers investigating whether investors reward socially responsible sovereigns with lower YTM. E.g., Gunther Capelle-Blachard et al., Sovereign Bond Yield Spreads and Sustainability: An Empirical Analysis of OECD Countries, 98 J. BANKING \& FIN. 156 (2019); Bastien Drut, Sovereign Bonds and Socially Responsible Investment, 92 J. Bus. ETHICs 131 (2010).

31. Stephanie Collet \& Kim Oosterlinck, Denouncing Odious Debts, 160 J. Bus. ETHICs 205, $217-$ 18 (2019).

32. See generally Stephanie Collet, The Financial Penalty for "Unfair" Debt: The Case of Cuban Bonds at the Time of Independence, 17 EUR. REV. ECON. HIST. 364 (2013).

33. Id. at 385 .

34. Kim Oosterlinck, The Bond Market and the Legitimacy of Vichy France, 40 EXPLORATIONS ECON. HIST. 326, 342-43 (2003).

35. See generally EWANS, supra note 3, at 84-108 (describing Leopold's eventually successful campaign to gain international recognition for his sovereign control of the Congo with the stated goals of ending the slave trade and bringing civilization and free trade to the region).

36. See generally Blocher, Oosterlinck \& Gulati, supra note 14 (exploring the timeline of the public understanding of Leopold's motivations in the CFS).

37. See EWANS, supra note 3, at 193 (quoting reformer and diplomat Roger Casement to the effect that "[ $\mathrm{t}]$ he root of the evil lies in the fact that the government of the Congo is above all a commercial trust, that everything is orientated towards commercial gain"); see also PAKENHAM, supra note 3, at 661 
through this period. This means that there are bonds that he issued in his early years (when the markets might have thought they were supporting a humanitarian venture) and those from the later years (when the venture had been revealed to be genocidal). Comparing the prices and YTMs on those bonds can give us a sense of whether the markets penalized the sinful bonds, as they did with the Hunger Bond in Venezuela and with the other despotic regimes analyzed.

\section{B. Successor Rewards: South Africa 1994}

In 1994, after years of internal struggle and widespread international condemnation, the apartheid government of South Africa was finally on its way out. The apartheid government had racked up nearly $\$ 20$ billion in debt while under United Nations sanctions. ${ }^{38}$ The existence of these sanctions did not automatically erase the obligation of the new, Nelson Mandela-led African National Congress government to pay the debts. But enforcing debt claims against a recalcitrant sovereign is not easy, and as a practical matter collecting payment on the debts would have been difficult, if not impossible.

And yet South Africa's new government paid in full the debts of its apartheid predecessor.$^{39}$ One likely explanation is that South Africa feared that repudiating the apartheid-era sovereign debt would hurt its future borrowing prospects. ${ }^{40}$ The question that interests us is whether, as a financial matter, South Africa made the right decision. ${ }^{41}$ Do markets indeed reward the payment of sinful debts?

The case of King Leopold's debts provides traction on this question because Belgium, which could have stiffed Leopold's creditors when it took over the CFS, did not. ${ }^{42}$ Like South Africa in 1994, Belgium paid the sinful debts. And because Belgium had its own bonds trading at the time when the decision to pay the King Leopold's sinful bonds was made, we can examine how investors in Belgian bonds reacted.

The economic theory of sovereign lending and borrowing often distinguishes between defaults that the market is willing to excuse (for example, defaults caused by factors out of the sovereign's control, such as an unexpected weather event) and those that it sees as a sign of irresponsibility (for example, a default

(citing the United States Consul-General's report that the CFS was not really a state but "one tremendous commercial organization").

38. See, e.g., Jeff Rubin, Challenging Apartheid's Foreign Debt, Probe InT'L (Apr. 1997), http:// probeinternational.org/library/wp-content/uploads/2011/02/RUBIN.pdf [https://perma.cc/LF68-YK32].

39. Mariam Isa, Apartheid Debt Settled, FIn24 (Sept. 3, 2001), https://www.fin24.com/Economy/ Apartheid-debt-settled-20010903 [https://perma.cc/633B-CGJ6].

40. For discussions of the reputational considerations, see, for example, STEPHANIA BONILLA, LAW AND ECONOMICS PERSPECTIVES 36 (2010); Unforgiveable, ECONOMIST (Apr. 24, 1999), https:// www.economist.com/finance-and-economics/1999/04/22/unforgivable [https://perma.cc/P6RZ-TLHQ].

41. Best we know, there is no research on this question as of yet. It is, however, one of the projects we are contemplating.

42. Of course, Belgium was differently situated in other ways, including the fact that it - more than South Africa's new government - had directly benefited from the prior borrowing. See infra Part V. 
caused by excessive spending). ${ }^{43}$ Did the market see Belgium's payment of the CFS debts as a sign that Belgium was a good debtor who paid those debts it might have resisted? Or did it see Belgium as an irresponsible debtor squandering resources on debts which the markets would have excused? Theory alone does not answer this question, so we use empirics. ${ }^{44}$

\section{III}

\section{BACKGROUND ON COLONIAL BONDS AND OUR DATA}

To understand our analysis of the CFS bonds, it helps to situate the analysis within the context of the broader literature on bonds of colonies. These bonds have received substantial attention from economists. In particular, research on British colony bonds suggests that they traded at lower YTMs than what local economic conditions would have warranted. ${ }^{45}$ That is, they were perceived as less risky than they should have been.

Scholars have suggested that the imperial power or mother country provided an implicit guarantee of the colonial bonds ${ }^{46}$ Despite the implicit guarantee, bonds issued by the imperial power itself usually trade at lower YTMs than bonds issued under the name of its colonies. However, the difference observed between these YTMs may reflect differences in other factors such as liquidity (with the mother country having greater liquidity).$^{47}$

Colonial status does not, however, unambiguously provide a borrowing benefit. Some researchers find, for example, that there are periods of historysuch as the period between World Wars I and II - when the benefit disappears. ${ }^{48}$ For example, once Britain left the gold standard, investors began to reassess

43. See generally Hershel I. Grossman \& John B. Van Huyck, Sovereign Debt as a Contingent Claim: Excusable Default, Repudiation and Reputation, 78 AM. ECON. REV. 1088 (1988) (identifying this market distinction).

44. This question has come up recently in the contexts of Mozambique and Malaysia. See Mark Weidemaier \& Mitu Gulati, Mozambique's Guarantees on the Tuna Bonds: Can They be Repudiated?, CREDITSLIPS (Jan. 27, 2019), https://www.creditslips.org/creditslips/2019/01/mozambiques-guaranteeson-the-tuna-bonds-can-they-be-repudiated.html [https://perma.cc/54LN-2244]; Mitu Gulati, Holiday Reading Recommendation and a Research Question, CREDITSLIPS (Nov. 25, 2018), https://www. creditslips.org/creditslips/2018/11/holiday-reading-recommendation-and-a-research-question-on-the1mdb-case.html [https://perma.cc/4NG7-MD5U].

45. See generally A.K. CAIRNCROSS, HOME AND FOREIGN INVESTMENT 1870-1913: STUDIES IN CAPITAL ACCUMULATION 222-35 (1953) (discussing how foreign investment in colonies traded at a premium compared to the risk for default); LANCE E. DAVIS \& ROBERT A. HUTTENBACK, MAMMON AND THE PURSUIT OF EMPIRE, THE POLITICAL ECONOMY OF BRITISH IMPERIALISM 1860-1912 (1986).

46. See Olivier Accominotti, Marc Flandreau \& Riad Rezzic, The Spread of Empire: Clio and the Measurement of Colonial Borrowing Costs, 64 ECON. HIST. REV. 385, 400 (2011) ("[P]owers with an international credit ended up acquiring subject nations and ... signaled ownership, and this was reflected in the market."). The data was kindly put at our disposal by the authors at http://eh.net/database/globalfinance/ [https://perma.cc/T5Y6-ZD8A].

47. Matthieu Chavaz \& Marc Flandreau, High \& Dry: The Liquidity and Credit of Foreign Government Debt in the First Age of Globalization (1880-1910), 77 J. ECON. HIST. 653, 686 (2017).

48. Maurice Obstfeld \& Alan M. Taylor, Sovereign Risk, Credibility and the Gold Standard: 18701913 versus 1925-31, 113 ECON. J. 241, 265-66 (2003). 
Britain's willingness (and ability) to guarantee bonds issued by its colonies. Independence movements, such as that in India, also led investors to question whether the guarantee would hold if the movements were successful. ${ }^{49}$

The case of the CFS differs from the typical colonial bonds in multiple ways. First, the CFS was not, strictly speaking, a colony of an imperial power. It was effectively the private property of the monarch of Belgium - King Leopold IIand, in that sense, an independent state. One, therefore, might not expect its bonds to receive the benefit of an implicit Belgian guarantee - at least not until it transitioned to a Belgian colony in $1908 .^{50}$

Second, the CFS went from being an independent state with bonds on the international market to being a colony. That kind of transition is rare, as a historical matter, since most transitions occur in the opposite order. It is even more uncommon to have data on bonds issued by the country before and after its change of status, which allows us here to examine how the transition affected bond YTM.

Over its existence between 1885 and 1908, the CFS issued several loans. Table 1 lists the details of these.

Table 1. List of Loans Issued by the CFS $^{51}$

\begin{tabular}{|c|c|c|c|c|}
\hline Loan & Decree & $\begin{array}{c}\text { Amount in } \\
\text { BEF }\end{array}$ & Convertibility & Other Elements \\
\hline $\begin{array}{c}2.5 \% \\
\text { 1887 Loan }\end{array}$ & $\begin{array}{c}\text { July 5, } \\
1887\end{array}$ & 422,200 & No mention & $\begin{array}{c}\text { As reimbursement for former member } \\
\text { of the Comité d'Etudes du Haut Congo }\end{array}$ \\
\hline $\begin{array}{c}\text { 1888 Lottery } \\
\text { Loan }\end{array}$ & $\begin{array}{c}\text { February } 7, \\
1888\end{array}$ & $150,000,000$ & No mention & Lottery \\
\hline $4 \% 1896$ & $\begin{array}{c}\text { October } \\
17,1896\end{array}$ & $1,500,000$ & $\begin{array}{c}\text { Not convertible for ten } \\
\text { years after the issue }\end{array}$ & $\begin{array}{c}\text { Issued to cover extraordinary expenses } \\
\text { linked to public works in the CFS }\end{array}$ \\
\hline $4 \% 1898$ & $\begin{array}{c}\text { June 14, } \\
1898\end{array}$ & $12,500,000$ & $\begin{array}{c}\text { Not convertible for ten } \\
\text { years after the issue }\end{array}$ & $\begin{array}{c}\text { Issued to cover extraordinary expenses } \\
\text { linked to public works in the Congo }\end{array}$ \\
\hline $4 \% 1901$ & $\begin{array}{c}\text { October } \\
15,1901\end{array}$ & $50,000,000$ & $\begin{array}{c}\text { Not convertible before } \\
1922\end{array}$ & $\begin{array}{c}\text { Issued to cover extraordinary expenses } \\
\text { linked to public works in the Congo }\end{array}$ \\
\hline $3 \% 1904^{52}$ & $\begin{array}{c}\text { February 1, } \\
1904\end{array}$ & $30,000,000$ & $\begin{array}{c}\text { Not convertible for ten } \\
\text { years after the issue }\end{array}$ & $\begin{array}{c}\text { Issued to cover extraordinary expenses } \\
\text { linked to public works in the Congo }\end{array}$ \\
\hline $4 \% 1906$ & $\begin{array}{c}\text { June 3, } \\
1906\end{array}$ & $10,000,000$ & $\begin{array}{c}\text { Exchangeable for a 3\% } \\
\text { Belgian loan in case of } \\
\text { annexation (option } \\
\text { valid for five years) }\end{array}$ & $\begin{array}{c}\text { Linked to railway construction. } \\
\text { Advance for an authorized issue to take } \\
\text { place later }\end{array}$ \\
\hline
\end{tabular}

49. See Nicolas Degive \& Kim Oosterlinck, Independence and the Effect of Empire: The Case of "Sovereign Debts" Issued by British Colonies, 38 (Ctr. Emile Bernheim, Working Paper No. 19-018, 2019), https://ideas.repec.org/p/sol/wpaper/2013-294694.html [https://perma.cc/FRC2-LAGZ].

50. See Blocher \& Gulati, supra note 4 , at 1220.

51. See generally Situation Financière et Budget Colonial, in No. 590, Ministère des Finances, Oud fonds, Archives Générales du Royaume, Brussels, Belgium (MIFINOUD); see also Fonds d'Amortissement de l'emprunt à lot de l'E.I. [hereinafter Fonds d'Amortissement], in No. 590, MIFINOUD; CONGO BELGE: RECUEIL ADMINISTRATIF DES FINANCES FASC. II app. at 29-32 (1912), in No. 592, MIFINOUD.

52. This bond as well as the 1901 bond only met limited success. An internal memo from the Belgian Ministry of Finance states that only half of the $3 \%$ loan had actually been issued and a notable part of the 4\% loan was still available for sale. See Emprunts Décrétés par l'Etat Indépendant depuis 1901, in No. 589, MIFINOUD. 


\begin{tabular}{|c|c|c|c|c|}
\hline Loan & Decree & $\begin{array}{c}\text { Amount in } \\
\text { BEF }\end{array}$ & Convertibility & Other Elements \\
\hline $\begin{array}{c}\text { 4\% Treasury } \\
\text { Bills }\end{array}$ & NA & $2,040,000$ & No mention & $\begin{array}{c}\text { Advance for an authorized issue to take } \\
\text { place later }\end{array}$ \\
\hline
\end{tabular}

Some of the bonds listed in Table 1 had unusual features, making them difficult to use for our purposes: the lottery feature of the lottery bond of 1888 , the limited liquidity of the partially issued bond of 1901, and the short maturity of the Treasury Bills of 1908. We exclude these three bonds from our analysis for these reasons. ${ }^{53}$

The 1888 lottery loan was particularly complex. The archives for the Belgian Minister of Finance show numerous attempts to assess the YTM of this bond..$^{54}$ Part of the complication was that the market did not take up all of the bond issue at issuance, thereby changing the originally estimated likelihood of a lottery win - a factor that then influenced the real YTM of the bond (only 916,875 out of 1,500,000 bonds were successfully marketed) ${ }^{55}$ To make things more complex, the CFS then passed a decree to convert the lottery bond into a $3 \%$ perpetuity in September $1903 .{ }^{56}$ But that attempt created controversy and was eventually abandoned. ${ }^{57}$ All of these events complicate an estimation of the YTM.

Like the 1888 lottery bond, the 1901 issue also met limited success. Belgian stockbroker Oscar Crabbe's testimony in the trial relating to Leopold's succession suggests that less than half of the bond was initially floated, with bonds subsequently being sold up until $1906 .{ }^{58}$ Again, the lack of accurate information regarding how much of the bond was issued and when complicates an accurate estimation of its YTM since the bond was likely to be illiquid.

Finally, twelve million francs worth of Treasury Bills were issued in 1908, when Leopold was forced to give up control of the CFS to Belgium. ${ }^{59} \mathrm{We}$ put these aside because it is not clear how involved the Belgian government was in these final issuances and, more importantly, whether the market perceived it to be involved. It seems plausible that investors perceived Belgian government involvement since Leopold had essentially been ejected by this point in time and the Belgian Finance Ministry was taking over. For example, we know from a

53. In addition to the loans in Table 1, the CFS also guaranteed a 25-million-franc loan issued by $L a$ Compagnie des Chemins de Fer des Grands Lacs, a railway company. See id.

54. See generally No. 587, MIFINOUD. Associating a lottery to a loan was disputed by some on moral grounds. The Antwerp stock exchange refused to list this lottery bond, because foreign lottery bonds were not allowed on their exchange. Despite pressures from the government, the bond was never listed in Antwerp. Emprunt du Congo, LE SOIR, Mar. 19, 1888.

55. Fonds d'Amortissement, supra note 51.

56. La conversion des lots du Congo, JOURNAL DES FINANCES (Fr), Oct. 3, 1903, at 4.

57. See, e.g., Conversion des lots du Congo (Oct. 06, 1903), in No. 587, MIFINOUD; Conversion de l'emprunt à lots du Congo (Oct. 14, 1903), in No. 587, MIFINOUD. The pressure to abandon the plan came from the French and Belgian governments. La Conversion des Lots du Congo, JOURNAL DES FINANCES (Fr.), Jan. 30, 1904, at 8.

58. Princess Louise of Belgium v. The Belgian State, Cour d'appel [CA] [Court of Appeal] Bruxelles, Apr. 2, 1913, Plaidoirie de Me Eugène Hanssens at 136-37.

59. See Note, in No. 591, MIFINOUD. 
handwritten document from the Belgian Ministry of Finance that the Société Générale de Belgique, the Banque Internationale de Bruxelles, and the Banque de Paris et des Pays-Bas were involved in these issues. ${ }^{60}$

In addition to the foregoing complications, a full set of pricing data for the 1901 loan and the Treasury Bills was not available.

IV

ANALYSIS

With this data in hand, we return to our two primary questions. First, we ask whether the markets, once news of Leopold's despotism became widespread, began to impose a sin penalty on his borrowing. Second, we ask whether Belgium received a market reward for paying Leopold's odious debts in full instead of trying to repudiate them.

For each of the CFS bonds included in our dataset, we collected weekly prices from the Courrier de la Bourse et de la Banque. ${ }^{61}$ The Courrier de la Bourse et de la Banque treated the 1896 and 1898 issuances as being the same and gave them a single price since they had similar characteristics. Therefore, we also treat them as being a single issue. Our sample ranges from January 1900 to December 1910. We picked this time range because it covers the period where we can be confident that the markets knew about Leopold's atrocities (around 1903), and goes until his removal (1907-08). To be safe, we add in a couple of years of data before and after. In general, the prices for all bonds move from week to week, suggesting that there was regular trading. To set these prices into perspective we also collected prices for the $4 \% 1909$ bond issued by the Belgian Congo (that is after the supposedly virtuous takeover by Belgium) and prices for a representative Belgian bond. ${ }^{62}$

To compare bonds with different maturities and different coupons we compute the YTM of the various bonds. The 1896, 1898, and 1906 loans were perpetuities. The 1901 and 1909 loans did not have a specific maturity but a sinking fund was created to buy them back on the market, and eventually extinguish the debt after 99 and 90 years respectively. We treat these bonds as if they had these maturities under the assumption that bondholders whose bonds

60. Sources available from authors.

61. The prices of all loans discussed in this Article were published weekly on Friday (and in case of public holiday, the earliest date before). Pricing data for the CFS $18964 \%$ and Belgian 3\% loans derive from research conducted by Sydartha Mikaba Kibingua. See Sydartha Mikaba Kibingua, The Debt of the Etat Indépendant du Congo (2012) (unpublished M.Sc. thesis, SBS-EM, Université Libre de Bruxelles) (on file with authors). Pricing data for all other loans derive from a physical review of the weekly issues of Courrier de la Banque et de la Bourse for the years 1900-10. These issues are available at the Bibliotheque Royal de Belgique [Royal Library of Belgium]. All data are on file with Law \& Contemporary Problems.

62. Decree of the 30 January 1909 , amount issued $6,800,000 \mathrm{BEF}$, coupon $4 \%$, non-convertible before 1920 , to be amortized in 90 years. 
had been recalled would use the proceeds of the sale to buy back a similar bond in order to maintain the same general portfolio balance. ${ }^{63}$

\section{A. Did the Markets Distinguish Between the Earlier and Later Bonds?}

Our first question regarding the CFS debt is whether, as news of Leopold's horrors in the CFS became public, the market began to impose a penalty on his borrowing - as researchers report happened with regard to sin stocks or, in the sovereign context, with certain Spanish debts in the late 1890s, the Tsarist Bond in 1906, and Venezuela's recent Hunger Bond. ${ }^{64}$

Leopold's borrowing is particularly useful for asking the foregoing question since his CFS bond issuances can be put into two distinctive categories: (1) the debt issued in his early years, roughly, 1885-1901, when many viewed him as a benevolent leader, and (2) the debt issued after 1903 and until his forced removal in 1908, by which time the world had learned of the horrors of his rule and that his primary motive was personal economic gain.

To the extent the markets imposed a penalty on sin-particularly on the bonds supported by lenders who were aware (or should have been aware) of the sin they were financing - we should see a higher market penalty imposed on the bonds issued after 1903.

Below, in Figure 1, we show the YTM patterns for four CFS bonds; in relative terms, two virtuous (the pre-1903 issuances) and two sinful (the post-1903 issuances). The dark vertical line at the end of October 1908 represents the date after which assumption of the CFS debts by the Belgian government became more certain. The results are remarkable in light of the very different results found in Collet (2013), Collet \& Oosterlinck (2018) and Gulati \& Panizza (2019), where the market penalized the sinful bonds. ${ }^{65}$ For the CFS, despite the fact that the sin in question was at least as large, if not many times worse, than in the aforementioned cases, there appears to have been no penalty imposed.

63. This is as in Collet \& Oosterlinck, supra note 31.

64. See supra Part II.

65. Collet, supra note 32; Collet \& Oosterlinck, supra note 31; Gulati \& Panizza, supra note 29. 
Figure 1. YTM of CFS Bonds ${ }^{66}$

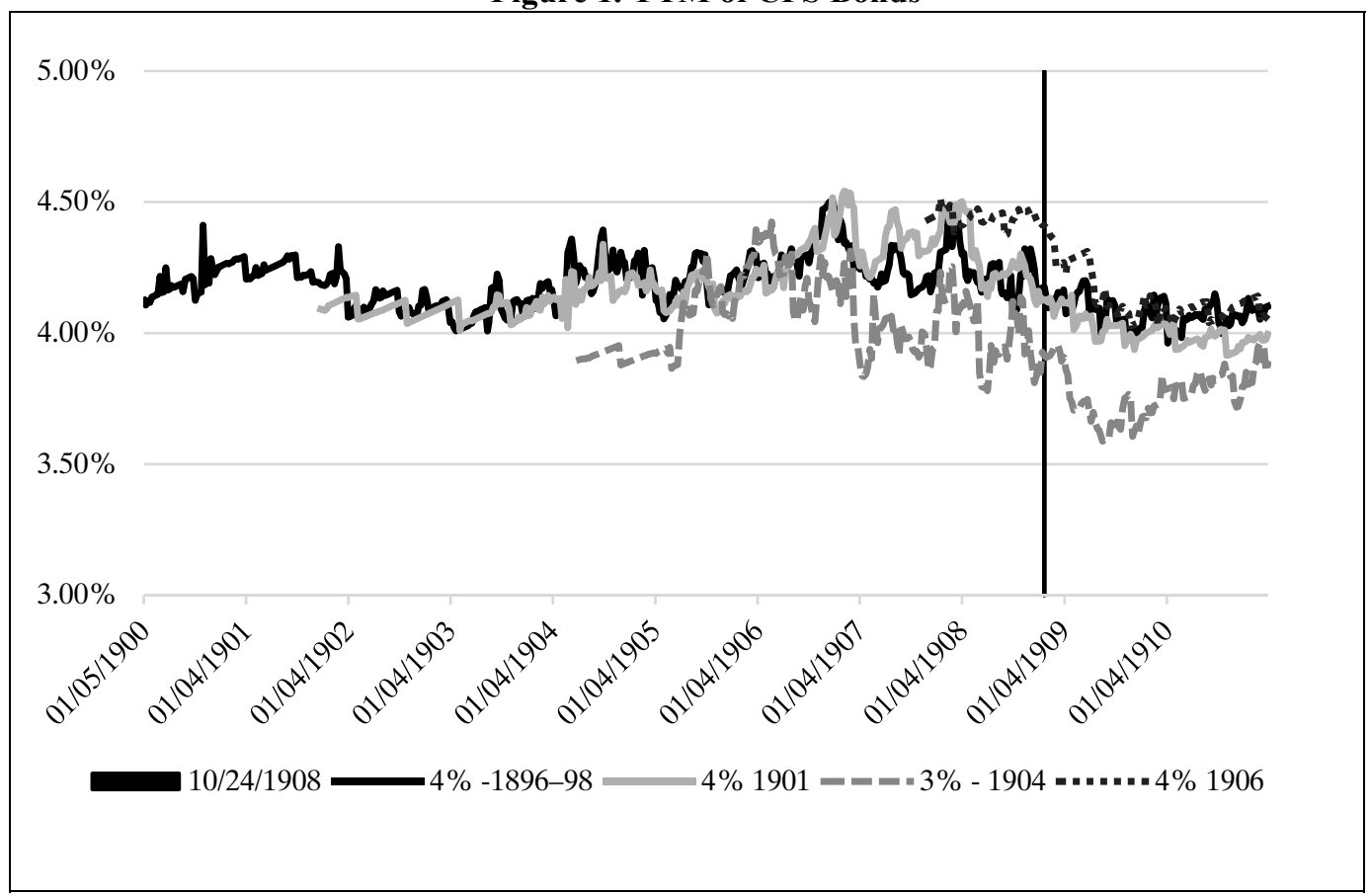

All four of the YTMs are very close, with the 1904 3\% loan slightly lower than the others, despite this being one of the sinful bonds. Table 2, which provides descriptive statistics for the YTMs of the various bonds, confirms this impression.

Table 2. Descriptive Statistics of the YTMs of the CFS Bonds ${ }^{67}$

\begin{tabular}{|c|c|c|c|c|}
\hline & $\begin{array}{c}\mathbf{1 8 9 6 - 9 8} \\
\mathbf{4 \%} \text { loan }\end{array}$ & $\mathbf{1 9 0 1} \mathbf{4 \%}$ loan & $\mathbf{1 9 0 4} \mathbf{3 \%}$ loan & $\mathbf{1 9 0 6} \mathbf{4 \%}$ loan \\
\hline Period & $1900-10$ & September 1901-10 & April 1904-10 & September $1907-10$ \\
\hline Minimum & $3.96 \%$ & $3.91 \%$ & $3.59 \%$ & $4.03 \%$ \\
\hline Maximum & $4.50 \%$ & $4.54 \%$ & $4.42 \%$ & $4.51 \%$ \\
\hline Median & $4.18 \%$ & $4.13 \%$ & $3.93 \%$ & $4.14 \%$ \\
\hline Mean & $4.18 \%$ & $4.15 \%$ & $3.96 \%$ & $4.24 \%$ \\
\hline
\end{tabular}

Since the bonds were issued at different points in time, the number of observations and the period covered differ across bonds. Despite this, the descriptive statistics show a similar pattern for all the CFS bonds with YTMs ranging from $3.59 \%$ to $4.54 \%$. Basically, over a period of ten years, we see the market treating all these bonds in essentially the same fashion. Therefore, the data show that the attacks made against Leopold's horrors in the CFS by the international press had at best a marginal impact on the bonds' YTMs. There is

66. The YTM data discussed in this Article derive from the authors' calculations, relying upon the collected prices and expiries of each bond at the relevant date. See supra notes 19, 51, 61 and accompanying text. All data are on file with Law \& Contemporary Problems.

67. Id. 
no break around 1904 when the press campaigns against Leopold's rule were prominent. This is opposite the expected outcome based on the results found by Collet and Oosterlinck for the 1906 Tsarist Bond and Panizza and Gulati for the Venezuelan Hunger Bond. ${ }^{68}$ In both those episodes, the authors ascribe an important role to the press in conveying the odious character of the bond, leading to a market penalty.

As noted earlier, our starting point in expecting the market to apply a price discount to the more odious or sinful bonds was two prior episodes at the end of the nineteenth and beginning of the twentieth centuries. The two historical episodes had to do with movement in the YTM of Spanish debt backed by Cuban revenues following the Spanish-American War of 1898 and the YTM of the 1906 Tsarist Bond.

The YTMs we see in Figure 1 and Table 2 stand in contrast with the results for the Tsarist Bond, which was denounced as odious by the French press and traded at some points in time at a YTM above 7\%. This contrast is even stronger with the Cuban 5\% loan which traded at a YTM of close to $20 \%$ during the negotiations following the Spanish-American War. ${ }^{69}$ This YTM reflected, in part, the costs of the war. But Collet shows that this bond, singled out as being odious, traded at close to 500 basis points more than another Cuban debt not viewed as odious. $^{70}$ The YTM patterns for the CFS and Belgian debts thus confirm that market participants were not treating the sinful and virtuous debts differentially.

Moreover, several bonds had conversion options: the state had the right to call back the bonds and ask bondholders either to accept a bond with a lower coupon or accept reimbursement. ${ }^{71}$ Conversion options are similar to call options. Bond prices reflect the expected revenues derived from holding the bond minus the value of the call option. ${ }^{72}$ Conversion options thus affect the YTM. ${ }^{73}$ In fact, by not taking this conversion option into account we overestimate the YTM. In other words, real YTMs are even smaller than the ones presented in Table 1, and the market imposed an even lower penalty than our data would suggest. ${ }^{74}$

68. Collet \& Oosterlinck, supra note 31; Gulati \& Panizza, supra note 29.

69. Collet, supra note 32; Collet \& Oosterlinck, supra note 31.

70. Collet, supra note 32 .

71. Henri Labeyrie, Théorie et Histoire des Conversions de Rentes Suivie D’une ÉTUDE SUR LA CONVERSION DU 5\% FRANÇAIS (1878).

72. In theory it is possible to compute the value of the option and to then compute the YTM. This requires making assumptions on the term structure of interest rates for which prices Congolese bonds without conversion option are needed. Unfortunately, these data do not exist.

73. Collet \& Oosterlinck, supra note 31; Kim Oosterlinck, Loredana Ureche-Rangau \& JacqueMarie Vaslin, Aristocratic Privilege. Exploiting “Good” Institutions (Ctr. Econ. Policy Research, Working Paper No. DP14071, 2019), https://cepr.org/active/publications/discussion_papers/dp.php?dpno=14071 [https://perma.cc/9H2C-XX5R].

74. The overestimation suggests an even lower market penalty on the CFS bonds than the one reported previously. The overestimation is nonetheless likely to be small. Indeed, all bonds were protected from conversion for a period of time and during our sample period only two bonds (the 1896 and 1898 loans) could be converted. See supra Table 1. Yet, their YTMs are very close to the YTMs of the other $4 \%$ loans in our sample suggesting the market attached little value to the option. Further, for the conversion option to be valuable, prices of the bond have at least to reach par. Otherwise, the state 
A different way of getting at the question of whether the markets distinguished between the sinful and more virtuous Congo bonds is to examine the relative YTMs of the CFS bonds and those of the Belgian Congo.

Figure 2 compares the YTM from July 1909 (when the Belgian Congo bond was first listed) to December 31, 1910. As in Figure 1, the YTMs of the 1904 CFS $3 \%$ bonds are slightly below the others (suggesting that the market liked the especially sinful bonds even more than the others). But, generally, the YTM of the Belgian Congo 1909 bond is indistinguishable from the CFS bonds. This view from Figure 2 is confirmed by the descriptive statistics in Table 3.

Figure 2. YTMs of the CFS and Belgian Congo Bonds ${ }^{75}$

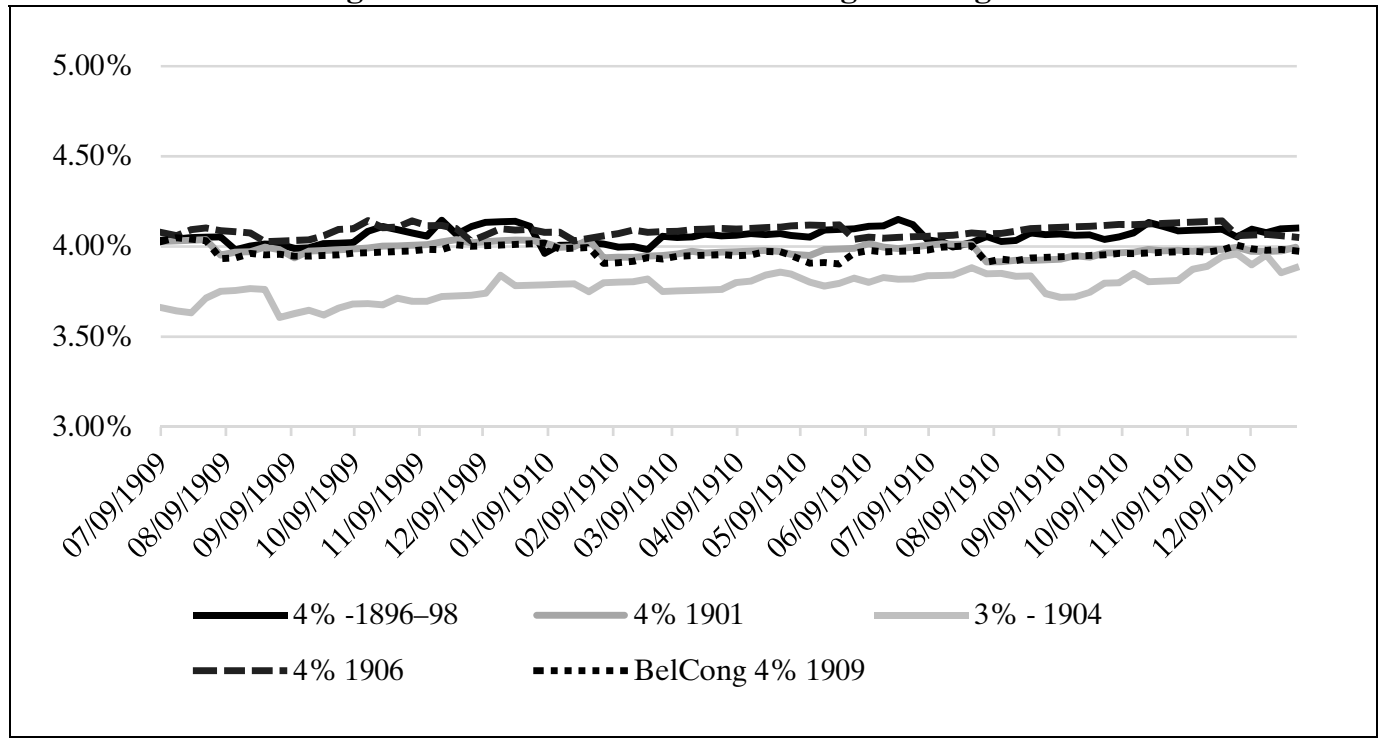

Table 3. Descriptive Statistics of the YTMs of the CFS and Belgian Congo Bonds ${ }^{76}$

\begin{tabular}{|c|c|c|c|c|c|}
\hline & \multicolumn{4}{|c|}{ CFS } & Belgian Congo \\
\hline & $1896-984 \%$ loan & $4 \% 1901$ & $3 \% 1904$ & $4 \% 1906$ & $4 \% 1909$ \\
\hline Minimum & $3.96 \%$ & $3.91 \%$ & $3.61 \%$ & $4.03 \%$ & $3.90 \%$ \\
\hline Maximum & $4.15 \%$ & $4.04 \%$ & $3.96 \%$ & $4.14 \%$ & $4.05 \%$ \\
\hline Median & $4.06 \%$ & $3.98 \%$ & $3.79 \%$ & $4.09 \%$ & $3.97 \%$ \\
\hline Mean & $4.06 \%$ & $3.98 \%$ & $3.78 \%$ & $4.09 \%$ & $3.97 \%$ \\
\hline
\end{tabular}

In sum, it does not appear that the market in the two years after the annexation of the CFS by Belgium treated its bonds any differently than those of

has no interest in calling the bonds since its current borrowing terms are less advantageous than the prevailing term for a given bond. Prices were indeed close to (and even sometimes above) par for the $4 \%$ bonds but not for the $3 \%$ one. With prices never exceeding $85 \%$ of par during our sample period, the $3 \%$ loan was unlikely to be converted. The YTMs on the $3 \%$ loan are slightly smaller than the ones observed on the other loans. This is consistent with a lower likelihood of conversion. The YTMs computed on the $3 \%$ loan are thus the least affected by the conversion option and will therefore be used as our favorite reference afterwards.

75. See supra note 66 .

76. Id. 
Belgian Congo. The Leopoldian colony and the Belgian colony were viewed by investors as essentially the same in terms of moral taint or repudiation risk. And this did not necessarily have to be the case, since other researchers have shown that the markets of that period were quite capable of distinguishing bonds based on their origin..$^{77}$

\section{B. Did Belgium Receive a Reward for Paying Leopold's Bonds?}

To examine whether Belgium received a market reward or penalty for choosing to pay the bonds of the CFS in 1908 and thereafter, we first compare the YTMs of the bonds of Belgium and the CFS before and after 1908 and then examine the spreads between those bonds before and after 1908 in Figures 3 and 4 , respectively. In particular, we are interested in the impact on the YTMs of Belgian sovereign bonds after the decision to pay these CFS bonds in 1907-08.

Drawing from pricing data collected by Mikaba Kibingua, ${ }^{78}$ we report below on a comparison of the YTMs of the CFS 1896-98 loan with the Belgian 3\% loan on a period ranging from 1899 to 1913. Kibingua finds that the spread between the two loans was relatively small. ${ }^{79}$ As mentioned previously, the 1896-98 loan was more likely to be called than the 3\% 1904 issuance. The 1904 loan series, however, begins later in our sample. We therefore report the YTMs for the $4 \%$ 1896-98 CFS loan, the 3\% 1904 loan, and the 3\% Belgian loan for the 1900-10 period in Figure 3.

77. Stephanie Collet, A Unified Italy: Sovereign Debt and Investor Skepticism 30-31 (Aug, 1, 2016) (unpublished manuscript), https://papers.ssrn.com/sol3/papers.cfm? [https:// perma.cc/6MJE-2NUD].

78. See Mikaba Kibingua, supra note 61.

79. See generally id. Her analysis reports semi-annual yield to maturity. Based on the raw data we computed the yearly YTM. 
Figure 3. Belgian and CFS Bond YTMs ${ }^{80}$

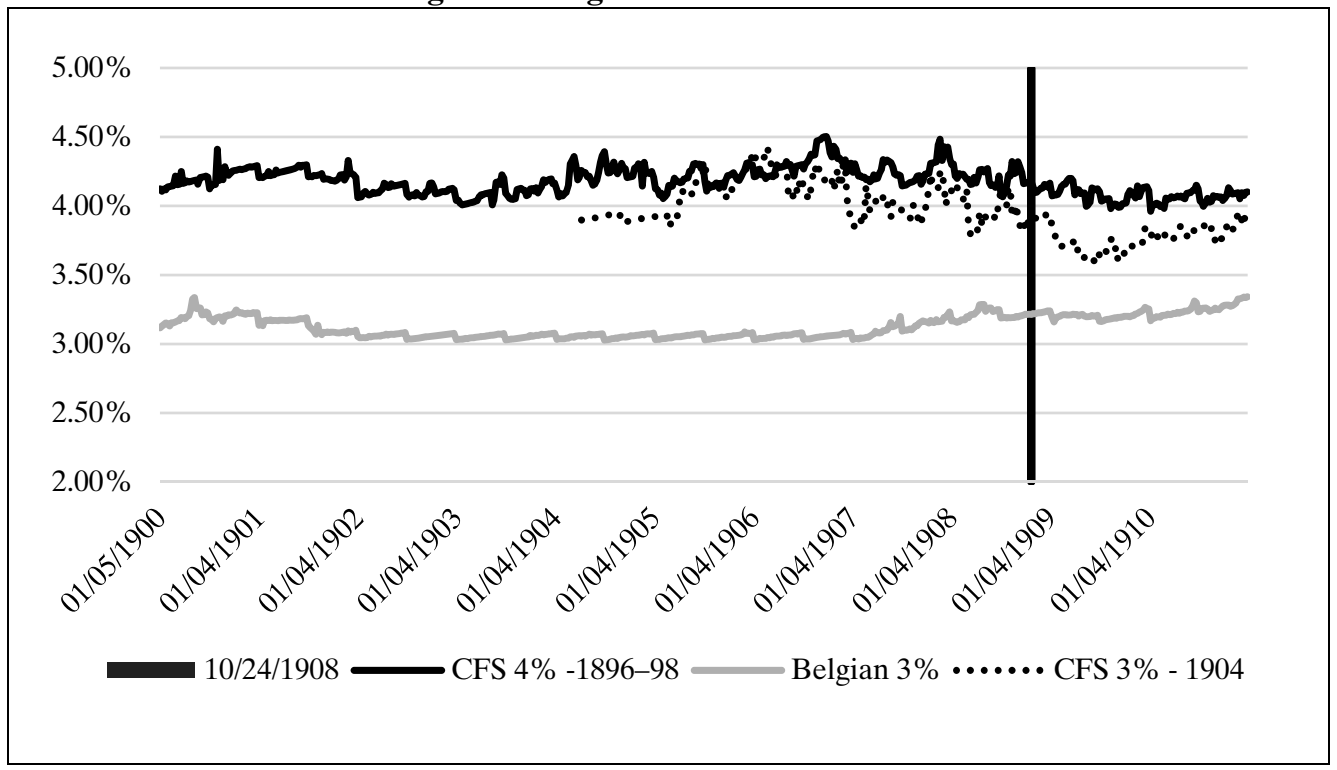

As we would expect, the YTMs on the bonds of the European colonizing power, Belgium, are lower than those of the CFS. What we are interested in, though, is whether Belgium, because of its decision to take on payment of the CFS bonds in 1908, was rewarded by the market for its "good debtor" behaviorpaying debts it arguably could have avoided-with a lowering of YTMs on its borrowing. Based on reports in the primary financial news outlet at the time, we estimate the rough date on which the market would have had confidence that Belgium was taking over the CFS debts as somewhere around the last week of October $1908 .{ }^{81}$ If the end of October 1908 is taken as reference point, the evolution of the Belgian bond YTMs does not show any form of reward. Indeed, the YTMs experienced a slightly increasing trend with an average YTM of $3.15 \%$ for the period ranging from the end of October 1906 to the end of October 1908, and $3.20 \%$ from the end of October 1908 to the end of October 1910. Increasing the size of the window shows an even more dramatic increase with Belgian YTMs reaching a value close to $4 \%$ in December 1912.

80. See supra note 66 .

81. The report in the Journal des Finances reads:

The law of annexation of Congo to Belgium, whose text has just been published in the Belgian Official Journal, draws attention of the market for these securities. Although the law has specified that the debts of the colony and the metropolis will remain separate, it is clear that Belgium is becoming morally responsible for servicing the Congolese debt, in the same way that the French state is morally responsible for the debts of his colonies. However, we know the firstclass security of Belgian finances. It is therefore ensured on the stock market that the prices of the Congo Lots, which, in recent days, are already showing signs of effervescence, are to quickly exceed the price of 100 francs.

Notes \& Arbitrages, JOURNAL DES FINANCES, Oct. 24, 1908, at 1011 (translation by authors). 
The CFS bonds, as one might expect, do go down in YTM when the Belgian state takes over the responsibility for paying them; news reports demonstrate that there was some uncertainty over whether the Belgian state would take on this responsibility. ${ }^{82}$ The transformation of the CFS into a colony was perceived by market participants as a sign that Belgium would from then on guarantee the CFS debt, and as a result bonds were treated as other colonial bonds were. Figures 4 and 5 show us what happened. Belgium's YTMs in the 1907-08 period do not fall, either when viewed on their own or in comparison to the CFS bonds. Instead, there is a rise in the YTMs. This rise in YTMs may reflect several fears, one of which being that Belgium implicitly recognized responsibility for a large debt not backed by enough resources. The bottom line: There is no indication that Belgium received a YTM benefit for taking on the responsibility for paying Leopold's debts. The ones who did benefit were those creditors who had lent Leopold the funds that supported his CFS misadventure.

Figure 4 provides the spread in the YTMs between the CFS bonds and the Belgian bond. This measure allows us to better assess the dynamics of the difference in the YTMs.

Figure 4. Spreads for CFS Bonds ${ }^{83}$

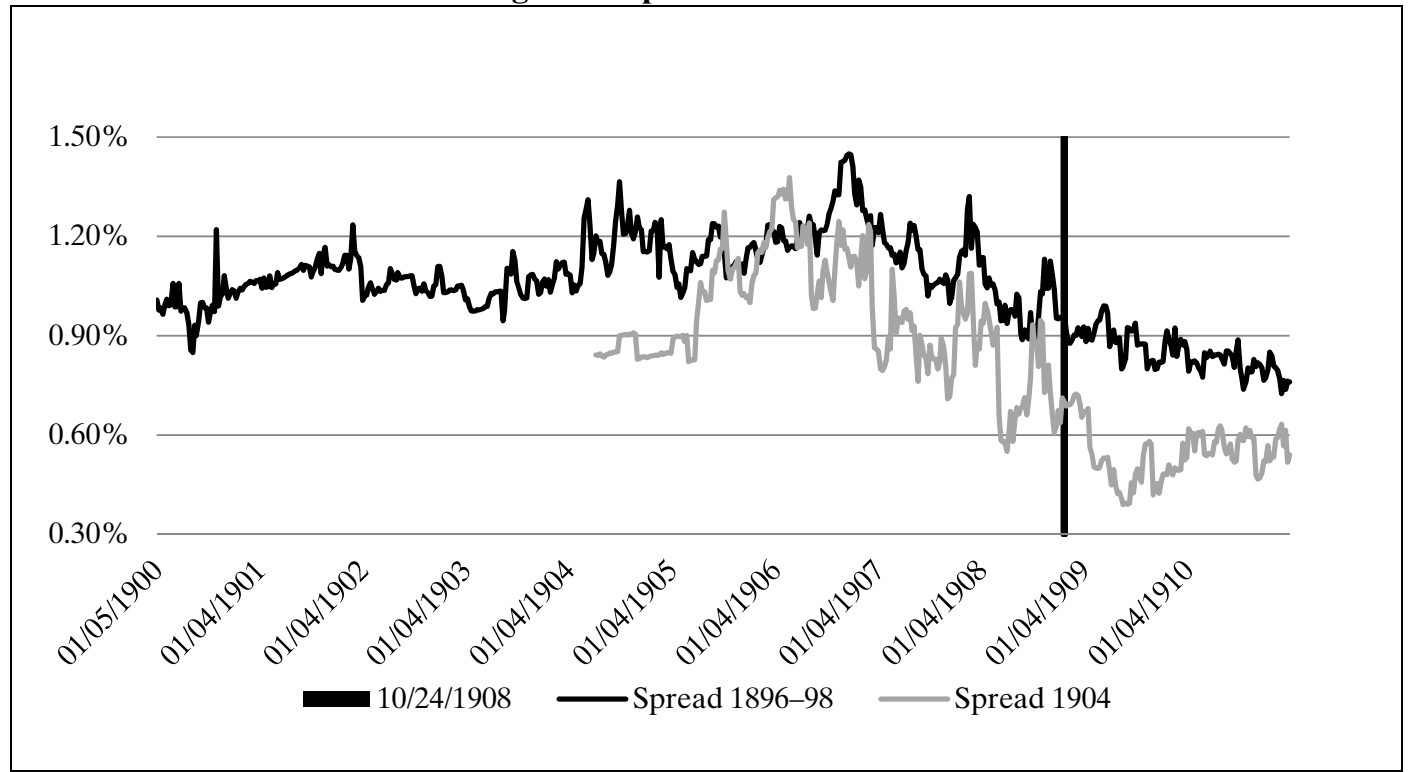

The spread peaks in 1906 for both loans. It remains generally relatively low. This is confirmed by the descriptive statistics presented in Table 4.

82. See Congo Deficit Likely: Belgium Bound Morally to Stand Sponsor, WASH. Post, Aug. 22, 1908 , at 3 .

83. See supra note 66 . 
Table 4. Descriptive Statistics of the YTMs of the CFS Bonds, the Belgian Bond, and their Spreads ${ }^{84}$

\begin{tabular}{|c|c|c|c|c|c|}
\hline & \multicolumn{2}{|c|}{ CFS } & Belgium & \multicolumn{2}{c|}{ Spread } \\
\hline & $\begin{array}{c}1896-98 \\
4 \% \text { loan }\end{array}$ & $19043 \%$ loan & $3 \%$ loan & $\begin{array}{c}\text { CFS 1896-98 4\% } \\
\text { loan - Belgium 3\% }\end{array}$ & $\begin{array}{c}\text { CFS 1904 3\% loan - } \\
\text { Belgium 3\% }\end{array}$ \\
\hline Period & $1900-10$ & April 1904-10 & $1900-10$ & $1900-10$ & April 1904-10 \\
\hline Minimum & $3.96 \%$ & $3.59 \%$ & $3.03 \%$ & $0.73 \%$ & $0.39 \%$ \\
\hline Maximum & $4.15 \%$ & $4.42 \%$ & $3.34 \%$ & $1.45 \%$ & $1.38 \%$ \\
\hline Median & $4.06 \%$ & $3.93 \%$ & $3.09 \%$ & $1.06 \%$ & $0.84 \%$ \\
\hline Mean & $4.06 \%$ & $3.96 \%$ & $3.13 \%$ & $1.06 \%$ & $0.82 \%$ \\
\hline
\end{tabular}

For the whole period, and relying on the overestimated YTM of the 1896-98 loan, the spread ranges from 73 to 145 basis points with an average of 106 basis points. ${ }^{85}$ When comparing the 1904 CFS bond and the Belgian bond YTMs, the spread averages only 84 basis points. In both cases the spread declines following the annexation, with the lowest values recorded after the annexation.

As a final comparison, we look at the spreads of a number of British colonies, to compare them to those of the CFS and Belgian Congo ${ }^{86}$ Figure 5 provides the spread with respect to the British consol for Canada, Cape Colony, Ceylon, Egypt, India, Jamaica, Mauritius, Natal, New South-Wales, New Zealand, Queensland, South Australia, Tasmania, Victoria, and Western Australia.

Figure 5. Spreads for British Colony Bonds ${ }^{87}$

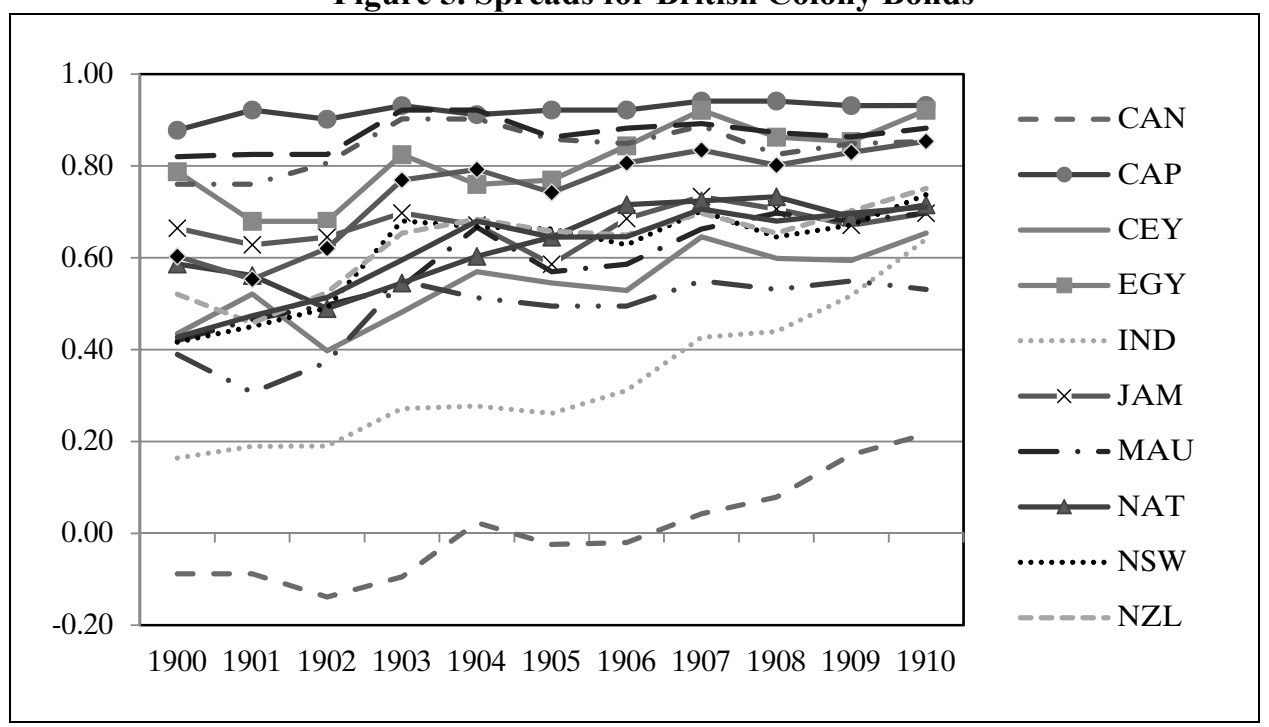

84. Id.

85. By 1910 (the end of our dataset) the 1896-98 could be converted, whereas the 1904 loans still had a protection from conversion. The overestimation of the YTM for this bond comes from the fact that the value of the conversion option for the bond cannot be accurately estimated. See supra text accompanying note 72 .

86. The data on YTM spreads between England and her colonies derive from the research by Accominotti et al., supra note 46.

87. Id. 
What the foregoing tells us is that the figures we discussed earlier for the CFS were the norm. Over the whole period the spreads for the British colonies are smaller than the CFS ones. However, once annexed to Belgium, the spreads become closer, in line with British colonies. If the market penalized the CFS bonds, or rewarded Belgium's guarantee of those CFS bonds, then the spread between the CFS and Belgian bonds would have remained greater than the spreads of the colonial bonds in Figure 5.

In other words, Belgium did not receive a market reward for paying for Leopold's sins. The bondholders who funded Leopold did, though. And that raises the question of why Belgium paid off the debts; we return to that puzzle in the conclusion.

\section{$\mathrm{V}$ \\ CONCLUSION: WHY DIDN'T THE DOG BARK?}

From the data analyzed above, nothing suggests that the markets imposed any penalty on King Leopold's borrowing, even though there was widespread international outrage against his behavior (including within Belgium itself). Indeed, the outrage was such that he was forced to give up power. Belgium then accepted responsibility for the CFS bonds and paid them, despite the fact that the usual explanation for why successor states pay the debts of prior despotsreputation - does not seem to hold here.

So, why didn't the Holmesian dog bark ${ }^{88}$ After all, we know from other research that markets do often impose a sin penalty on financial securities associated with bad behavior. ${ }^{89}$ There are three potential reasons, all of which will require further research to assess.

\section{A. Self-Interest on the Part of Belgian Officials}

Our first conjecture has to do with possible financial self-interest on the part of powerful actors in Belgium. This explanation was raised in 1908 by members of the Parti Ouvrier Belge [Belgian Labor Party], when the socialist politician, Jules Destrée, accused the members of the right-wing parties of acting in selfinterest to paper over Leopold's odious debts because to have called them into question would have also called into question their own substantial investments in the Congo. ${ }^{90}$

The Belgian socialist newspaper, Le Peuple, went as far as to publish a list of legislators involved in these investments. According to the socialist leader, the

88. Sherlock Holmes' creator, Sir Arthur Conan Doyle, was famously a key part of the humanitarian campaign against Leopold, along with Mark Twain and Joseph Conrad. See, e.g. ARTHUR CONAN DOYLE, THE CRIME OF THE CONGO (1909); Blocher \& Gulati, supra note 4, at 1238 n.115.

89. See supra Part II.

90. See generally Séance du Venrendi 18 Juin 1908, 8 Annales Parlementaires de la Chambre des Représentants 47-60 (statements of M. Destrée). 
state taking over the debts of the CFS was a way of legitimizing the problematic concessions made to the private firms that many powerful Belgians were benefiting from. ${ }^{91}$

\section{B. No Press Focus on Bad Bonds}

In both the stories about the 1906 Tsarist Bond and the Venezuelan Hunger Bond, the international press focused on and discussed the problematic provenance of the bonds in question (for example, that they were issued without appropriate legislative approval or severely underpriced). ${ }^{92}$ In our examination of the historical record, we found no articles casting doubt on the validity of any of Leopold's debt issuances at the time they were made. Maybe, for the market to impose a penalty on a sin bond, there needs to be a precursor in the form of negative press attention that then catches fire.

\section{Belgium's Own Culpability for Leopold's Sins}

The final possibility has to do with Belgium's own culpability regarding the exactions made in the Congo. The question of Belgium's culpability for Leopold's excesses is a much debated one. Leopold, after all, was the king of the Belgians all through the period of his rule of the CFS. And while it is clear that there was reluctance on the part of the Belgian government to become a colonial power, Belgium was one of Leopold's biggest creditors all through his reign. Indeed, but for Belgium providing crucial financial support at key moments, Leopold's reign in the Congo would have likely ended long before it actually did.

Further, Leopold used his ill-gotten gains to build grand palaces and fancy gardens in Belgium. ${ }^{93}$ So, maybe the markets neither penalized the tainted CFS bonds, nor subsequently rewarded Belgium for taking them on, because of a collective market judgment that a significant enough portion of the moral taint lay with Belgium itself. Belgium, in essence, had primary moral responsibility for constraining Leopold (at least as compared to general bondholders) and it, more than anyone else, reaped the rewards of Leopold's bad behavior.

We have seen from the prior research described in Part II that markets can and do sometimes impose penalties on immoral behavior. But perhaps what we are seeing here is that there are limits to crowdsourced disapproval; that it is a lot less effective in penalizing bad behavior when judgements about comparative fault are at issue. ${ }^{94}$ And that then leads to the question of whether there is a need

91. Id. at 31 ("The interest of the concessionary companies in Belgium taking over the succession of the Congo Free State is not debatable .... If Belgium assumes, as regular and valid, the obligations of the Congo Free State, the interests of the companies are fully insured.”).

92. See Collet \& Oosterlinck, supra note 31, at 218; Panizza \& Gulati, supra note 27, at 28.

93. Jean Stengers, King Leopold's Imperialism, in STUDIES IN THE THEORY OF IMPERIALISM 248, 261 (Roger Owen \& Bob Sutcliffe eds., 1972) (noting that Leopold "did make money out of the Congo, but he used it almost exclusively to enrich the Belgian national heritage by acquiring property, building monuments and developing towns").

94. As of this writing, there has been little consideration in the odious debt literature of situations where judgements about comparative fault need to be made. See generally Mitu Gulati \& Omri Ben- 
for formal legal sanctions, and how that sanctioning mechanism may best be designed. the potential allocation of odious debt costs among parties after a despot has been dethroned. 